\title{
Bcr-abl translocation can occur during the induction of multidrug resistance and confers apoptosis resistance on myeloid leukemic cell lines
}

\author{
Francis Belloc $^{1,2}$, Sophie Cotteret ${ }^{1,2}$, Gilles Labroille ${ }^{1,2}$, \\ Valérie Schmit ${ }^{1}$, Claudine Jaloustre ${ }^{1}$, Patrice Dumain', \\ Françoise Durrieu², Josy Reiffers ${ }^{3}$, Michel R. Boisseau', \\ Philippe Bernard ${ }^{1,2}$ and Francis Lacombe ${ }^{1,3}$

\footnotetext{
1 Laboratoire d'Hématologie, Hôpital haut Lévêque, 33604 Pessac, France

${ }^{2}$ Laboratoire Universitaire d'Hematologie, Université Victor Segalen, 33076 Bordeaux, France

${ }^{3}$ CNRS-UMR 5540, Université de Bordeaux II, 33000 Bordeaux, France

${ }^{4}$ corresponding author: F. Belloc, Laboratoire de Cytométrie en Flux, Hématologie, Hôpital Haut Lévèque, 33604 Pessac cedex, France. tel: (33) 556556565 ext. 33711; fax: (33) 556556845 .
}

Received 24.3.97; revised 14.7.97; accepted 14.7.97

Edited by M. Piacentini

\begin{abstract}
Apoptosis was studied in parental and mdr-1 expressing U937, HL60 and K562 myeloid leukemic cell lines using mdr unrelated inducers of apoptosis such as Ara-C, cycloheximide, serum deprivation, ceramide, monensin and UV irradiation. Apoptosis was efficiently induced by all these treatments in U937 and HL60 cells while K562 cells exhibited an apoptosis-resistant phenotype except with UV and monensin. The pattern of apoptosis resistance in mdr-1 expressing U937 (U937-DR) and HL60 (HL60-DR100) was similar to that presented by K562. This apoptosis-resistant phenotype of mdr cells was not overcome by concentrations of verapamil inhibiting the P-gp 170 pump. The acquisition of this phenotype was posterior to the mdr-1 expressing phenotype since a HL60-DR5 variant, selected at the beginning of the induction of resistance, presented a low level of mdr-1 expression without resistance to apoptosis. The variations observed in the Fas (CD95) expression between sensitive and resistant cells were not sufficient to account for apoptosis resistance. However, a high expression in Abl antigen was found in all the apoptosis-resistant cells. RT-PCR and Western blot analysis showed that this increase in Abl antigen content was accompanied by the expression in U937-DR and HL60-DR100 cells of a hybrid bcr/ abl mRNA and a $210 \mathrm{kD} \mathrm{Bcr/Abl}$ protein which was constitutive in K562. This expression was due to the translocation of abl and the amplification of the bcr-abl translocated gene. These results are in agreement with the role of $\mathrm{Bcr} / \mathrm{Abl}$ tyrosine protein kinase as an inhibitor of apoptosis independently of the mdr-1 expression. They also suggest that translocation of the abl gene in the bcr region is a highly probable rearrangement in the mdr-1 expressing myeloid cells and that Bcr/Abl tyrosine kinase effect on
\end{abstract}

apoptosis needs the regulation of intracellular $\mathrm{pH}$ and is inactive against UV-induced apoptosis.

Keywords: apoptosis; bcr-abl translocation; leukemia; multidrug resistance

Abbreviations: abl, abelson; AIDS, acquired immuno depressive syndrome; Ara-C, cytosine arabinoside; ATP, adenosine triphosphate; bcr, breakpoint cluster region; BrdUrd, bromodeoxyuridine; DNA, deoxyribonucleotidic acid; dCTP, deoxycytidne triphosphate; dGTP, deoxyguanidine triphosphate; dNTP, deoxynucleotide triphosphate; dUTP, deoxyuridine triphosphate; DNA, deoxyribonucleotidic acid; DNR, daunorubicine; DTT, dithiothreitol; EDTA, ethylenediaminetetraacetic acid; FCM, flow cytometry; FCS, foetal calf serum; FISH, fluorescent in situ hybridization; HEPES, hydroxyethyl piperazineethanesulfonic acid; Ig, immunoglobuline; mdr, multi drug resistance; PBS, phosphate buffered saline; PCR, polymerase chain reaction; P-gp, phospho-glycoprotein; PI, propidium iodide; PMSF, phenylmethylsulfonyl fluoride; $\mathrm{Rh}$, rhodamine; RNA, ribonucleotidic acid; Rnase, ribonuclease; RT, reverse transcriptase; SDS, sodium dodecyl sulfate; TdT, terminal deoxynucleotidyl transferase; Tris, tris(hydroxymethyl)aminomethane; UV, ultra-violet

\section{Introduction}

Tissue and cell culture expansion or renewal result from cell elimination and proliferation. Physiological elimination is due to active cell death or apoptosis where the cell triggers a genetic program which induces enzyme and antigen expression leading to its death. Recently, oncologists and haematologists became interested in apoptosis which was described by embryologists in the fifties (Wyllie, 1992). Physiological apoptosis can be defined as cell suicide on behalf of the whole organ or organism. This 'altruistic behaviour' is modulated by the cellular and humoral environment of the cell and it has been demonstrated that disturbed apoptosis is at the origin of pathologic states owing to inhibition (tumors, viral infections, autoimmune syndromes) or exacerbation (AIDS). Moreover, all the drugs used in the treatment of leukemia have been shown to induce apoptosis in vitro (Vial et al, 1996) and the triggering of apoptosis in tumoral cells could be one of the in vivo mechanisms of these drugs (Gorczyca et al, 1993; Li et al, 1994; Hicsonmez et al., 1996).

Multidrug resistance is the major cause of failure in cancer therapy and is due to several mechanisms. The most frequently described and the most often studied mechanism is the expression of the mdr-1 gene. This gene encodes for a $170 \mathrm{kD}$ ATP binding P-glycoprotein (Pgp- 
170). The most generally accepted hypothesis for multidrug resistance is that the Pgp-170 acts as a pump to exclude therapeutic agents from the cell (Gottesman and Pastan, 1993), thus decreasing the intracellular concentration of the drug.

Several other mechanisms of multidrug resistance, however, have been described, among which modifications in intracellular pH (Simon et al, 1994) and diminished apoptosis response (Frankfurt et al, 1994). Such a survival advantage has been associated in tumoral cells with overexpression of bcl-2 protein (Campos et al, 1993; Miyashita and Reed, 1993), or Abelson protein tyrosine kinase (Chapman, et al, 1995).

In this work, we studied the susceptibility of Pgp-170 expressing leukaemia cell lines to undergo apoptosis when submitted to Pgp-170 unrelated stimuli able to induce apoptosis. It was found that cells with a high expression of Pgp-170 also exhibited an apoptosis-resistant phenotype which was accompanied by the expression of the Bcr/Abl protein tyrosine kinase and could be overcome by UV irradiation or monensin treatment.

\section{Results}

\section{Characterisation of mdr-1 expression in the different cell lines}

This work was performed on three different cell lines and their mdr-1 expressing sublines: U937 and U937-DR, K562 and K562-DR and HL60 with two sublines exhibiting different resistance indexes to DNR, HL60-DR5 and HL60-DR100. The rate of expression of the mdr-1 product, Pgp-170, was evaluated by immunolabelling and FCM analysis. Figure $1 \mathrm{~A}$ shows that the three U937-DR, K562-DR and HL60-DR100 exhibited similar levels of Pgp-170 expression. This expression was maintained at a very low but still detectable level in the HL60-DR5 cell line when compared to the parental sensitive HL60 (ratio DR5/sensitive $=1.3 \pm 0.4$ ). The HL60DR5 cell line was able to grow in the presence of $10 \mathrm{nM}$ DNR. At this concentration, the parental HL60 which did not express Pgp-170 was blocked in G2 (not shown). Moreover, Figure 1B shows that HL60-DR5 expressed detectable level of mdr-1 mRNA; the three parental cell lines were negative for mdr-1 mRNA expression while HL60-DR100, U937-DR and K562DR expressed large amounts (when compared to HL60-DR5) of mdr-1 mRNA.

\section{Efficiency of UV irradiation and monensin in inducing apoptosis in mdr-1 expressing cells}

Several inducers of apoptosis were tested on U937, K562 (which is known as a poor responder to apoptosis) and their DR sublines. Two of them were found to be able to induce apoptosis in both parental and DR U937 and K562. One min. UV-B irradiation was then sufficient to trigger apoptosis in the four cell lines (Figure 2A). Thus, these cell lines were not defective in the sphingomyelin signal transduction pathway, which is a common pathway to apoptosis for ionizing radiation (Kolesnick et al, 1994), UV (Wright et al, 1996) and DNR (Jaffrezou et al, 1996).

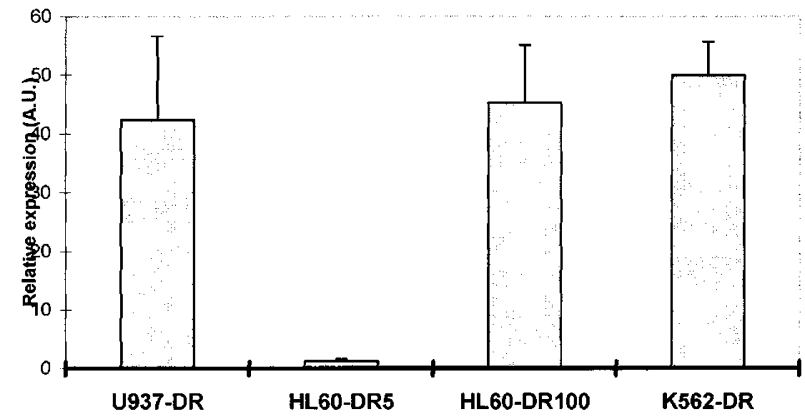

b

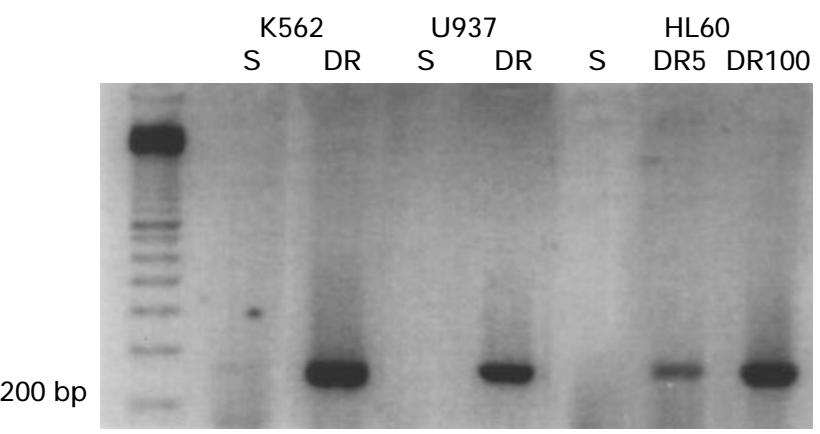

Figure 1 Relative expression of Pgp-170 in the resistant cell lines. (A) U937, HL60, K562 and their DNR resistant sub-line (DR) were labelled with anti Pgp170 antibodies and analyzed by FCM as described in Materials and Methods. The mean+S.D. of three separate determinations are shown. (B) agarose ge electrophoresis of mdr-1 RT-PCR fragments amplified from total mRNA extracted from the seven cell lines.

$\mathbf{A}$

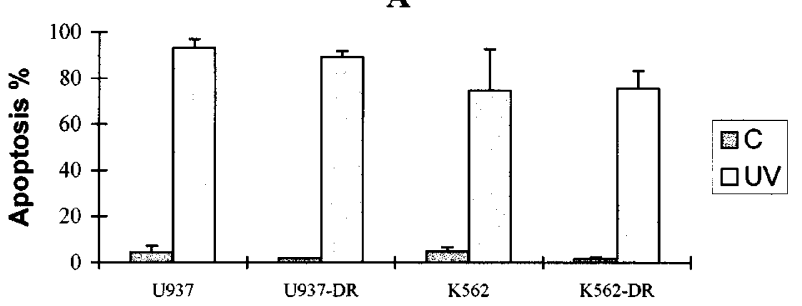

B

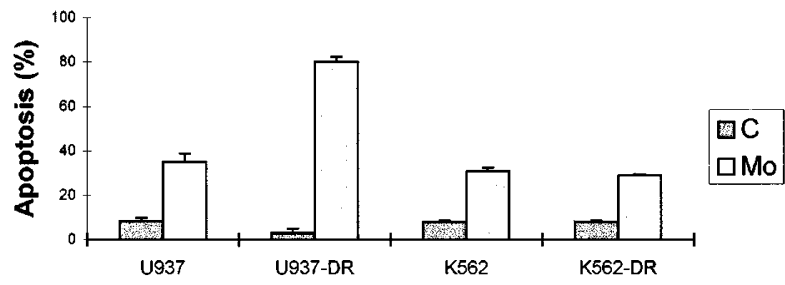

Figure 2 Effect of UV illumination and monensin treatment on the apoptosis of sensitive and DRU937 and K562. (A) U937, K562 cells and their DR sublines were UV-B irradiated on a UV transilluminator for $1 \mathrm{~min}$ and were incubated for $18 \mathrm{~h}$ before apoptosis determination. (B) U937, K562 cells and their DR sublines were incubated for $18 \mathrm{~h}$ in the presence of $50 \mu \mathrm{M}$ monensin before apoptosis determination. Untreated controls (dark bars) were processed in parallel for each experiment. The means \pm S.D. of three seperate experiments are shown. 
Alterations in cytoplasmic or organelle $\mathrm{pH}$ have often been associated with apoptosis (Barry et al, 1993) and with multidrug resistance (Simon et al, 1994). Treatment of the cells with monensin, an ionophore which equilibrates the $\mathrm{pH}$ in all cell compartments (Maxfield, 1982), was also able to induce a significant apoptosis (Figure 2B). The efficiency of UV and monensin in inducing apoptosis in the apoptosisresistant cells suggests that these cells are equipped with all the molecules necessary for apoptosis completion.

\section{Apoptosis susceptibility of $\mathrm{mdr}-1$ expressing cells under two mdr-1 unrelated drug treatments}

Amongst the drugs which were used to induce apoptosis, some were found to be inefficient on mdr-1 expressing cells. The U937-DR cells were as sensitive as U937 to DNA synthesis inhibition by Ara-C which is not a substrate for Pgp170 (Figure $3 \mathrm{~A}$ ), and a $50 \%$ inhibition was obtained by $10^{-7} \mathrm{M}$ Ara- $\mathrm{C}$ in both cell lines. However, while high concentrations of Ara-C led to apoptosis induction in the U937 sensitive cells with $50 \%$ apoptosis in $18 \mathrm{~h}$ at $10^{-5} \mathrm{M}$, no apoptotic cells with fragmented DNA were detected in U937DR even at $10^{-3} \mathrm{M}$ Ara-C (Figure 3B).

U937, HL60, K562 and their derived resistant sublines were treated with cycloheximide $(\mathrm{CHX})$, a protein synthesis

Inhib. S (\%)

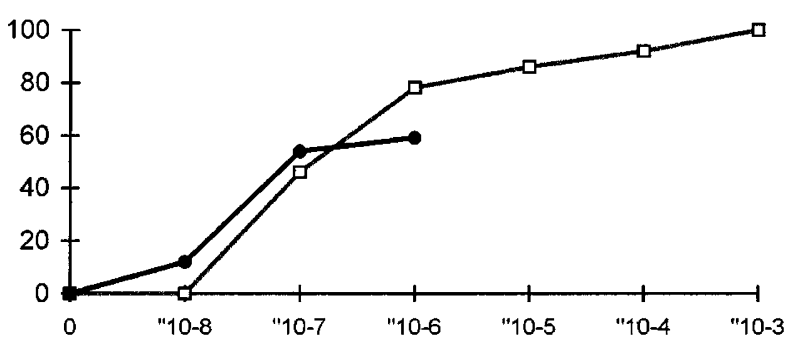

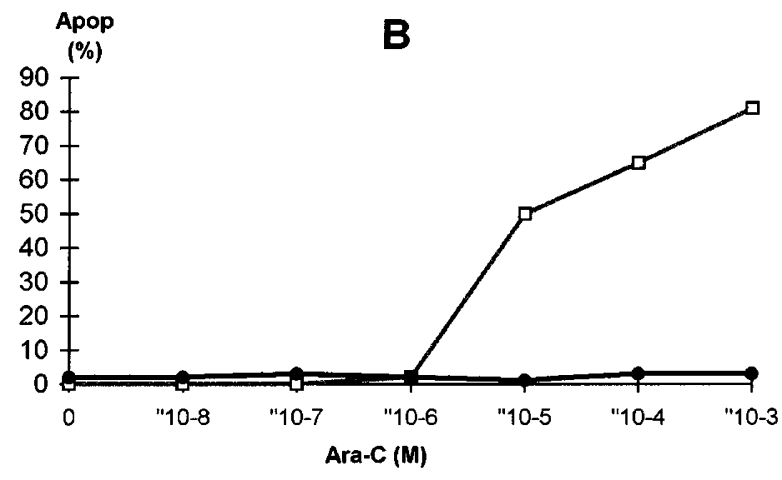

Figure 3 Effect of Ara-C on sensitive and mdr U937. (A) U937 sensitive (white squares) or DR (black circles) were incubated for $3 \mathrm{~h}$ with increasing concentrations of Ara-C $\left(10^{-8}\right.$ to $\left.10^{-3} \mathrm{M}\right)$ and inhibition of DNA synthesis was measured by BrdUrd incorporation and FCM analysis as described in Materials and Methods. The percentage of inhibition was plotted as a function of Ara-C concentration. (B) U937 sensitive (white squares) or DR (black circles) were incubated for $16 \mathrm{~h}$ with $\mathrm{Ara}-\mathrm{C}$ as in $(\mathbf{A})$. Apoptosis was then measured by the TdT labelling of DNA fragmentation and FCM analysis. The percentage of apoptotic cells was plotted as a function of Ara-C concentration. inhibitor which is not excluded by the Pgp-170 and which has been described to induce apoptosis in leukaemia cell lines. $\mathrm{CHX}$ progressively induced apoptosis in HL60, in U937 and in the weakly resistant HL60-DR5 (Figure 4). These concentrations of $\mathrm{CHX}$, however, remained without effect on high mdr-1 expressing HL-DR100 and U937-DR. Both K562 and K562-DR appeared to resist the induction of apoptosis by $\mathrm{CHX}$ (Figure 4).

\section{Apoptosis susceptibility of $\mathrm{mdr}-1$ expressing cells under growth factor privation}

To verify if the relative resistance to apoptosis induction observed in some cell lines was restricted to chemical induction, a more physiological mechanism of induction was investigated. The different sensitive and resistant cell lines were deprived in growth factors by $48 \mathrm{~h}$ culturing in serumfree medium, and apoptosis was then measured (Figure 5). Both U937-DR and HL60-DR100 cells were found to exhibit a limited apoptotic response to these conditions. The weakly mdr-1 expressing HL60-DR5 remained sensitive to serum deprivation and underwent an apoptotic response comparable to HL60. As for CHX treatment, both K562 and K562-DR cells responded weakly to growth factor deprivation by apoptosis. It must be noticed that although greatly reduced, the apoptosis response was not completely abolished in HL60-DR100, U937-DR and both K562 cell lines, and that some cells with characteristic apoptotic features could be observed in these conditions. The growth was completely inhibited under these culture conditions in all the cell lines (not shown).

Such results could be explained by a defective release of the second messenger during the transduction signal. We thus shunted this release and induced apoptosis by directly using ceramide which is supposed to be the cytoplasmic messenger of the apoptotic signal. It can be seen in Figure 5B that the cells which were poor apoptosis responders to serum deprivation were also poor responders to ceramide treatment. Thus, a transduction deficiency in

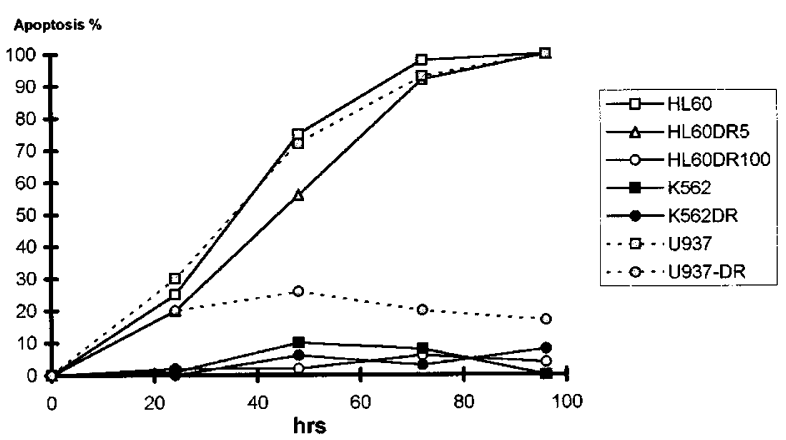

Figure 4 Effect of cycloheximide on sensitive and mdr HL60 and K562 cells. HL60 and K562 cell lines and their DR sublines were treated with $1 \mu \mathrm{g} / \mathrm{ml}$ of cycloheximide. Apoptosis was microscopically determined using the acridine orange method and the percentages of fragmented nuclei were plotted as a function of incubation duration. White squares: HL60; white triangles: HL60DR5; white circles: HL60-DR100; grey squares, dotted line: U937; grey circles, dotted line: U937-DR; black squares: K562; black circles: K562-DR. 
these cells cannot account in itself for apoptosis deficiency.

Although poor apoptotic response was not restricted to mdr-1 expressing cells (i.e. K562), it was interesting to check a possible relationship between Pgp-170 activity and apoptotic potential. It has been shown that a mdr-1 expressing HL60 variant was resistant to the cytotoxicity of the complement and that this resistance was inhibited by verapamil, an inhibitor of Pgp-170 (Weisburg et al, 1996). Inhibiting the extrusion activity of Pgp-170 by $12 \mu \mathrm{M}$ verapamil on U937-DR cells failed to restore a normal apoptotic response to serum deprivation (Figure 6). Verapamil treatment was also found to be inefficient to restore apoptosis after serum deprivation on HL60-DR100 and K562-DR (not shown). This verapamil concentration was sufficient to restore $80 \%$ of DNR accumulation in the DR cells (Boiron et al, 1994) and to inhibit the exclusion of rhodamine 123 (Figure 6).

Pgp-170 could also be responsible for the apoptosisresistant phenotype, for example, by excreting the ceramides released by the action of sphingomyelinase (Wright, 1996; Jaffrezou et al, 1996) or ceramide synthase (Bose et al, 1995) when apoptosis is triggered, as ceramides have been described as substrates for Pgp170 (van Helvoort, 1996). In our experimental conditions, however, Pgp-170 failed to exclude a fluorescent analogue of C2-ceramide (Figure 6), so an antagonistic effect of Pgp170 towards this second messenger could be ruled out.

\section{Susceptibility of sensitive and drug-resistant cells to Fas-mediated apoptosis}

Fas is a receptor which triggers a death message inside the cell when it is occupied by its ligand or by an IgM antibody. Because Fas is physiologically implicated in various mechanisms of apoptosis, we measured the expression of Fas on the membrane of sensitive and DR U937, HL60 and K562 (Figure 7A). Fas expression was found to be decreased in all the cell lines exhibiting a defective apoptosis response: K562 and the three K562, U937 and HL60 DR cell lines. The rate of Fas expression on these cells was 2.5 and 5 times lesser than on HL60 and U937 respectively. The Fas binding $\mathrm{CH}-11 \mathrm{lgM}$ was unable to induce apoptosis in $\mathrm{K} 562$ and DR cell cultures (Figure 7B). This IgM induced $70 \%$ of apoptotic U937 cells in $18 \mathrm{~h}$ but only $12 \%$ of apoptotic HL60.

\section{Expression of $\mathrm{Abl}$ in apoptosis-resistant and sensitive cells}

The Abl protein-tyrosine kinase was shown to be an important apoptosis-preserving protein. We used immuno-fluorescence and FCM to measure the expression of the Abl antigen (Figure $8 \mathrm{~A})$ and found an increase in the Abl content in all four apoptosis-resistant cell lines U937-DR, HL60-DR100 and both $\mathrm{K} 562$ when compared to the apoptosis-competent U937 and HL60 cell lines. The histograms of fluorescence distribution showed a homogenous increase of Abl expression in the whole cell population (not shown).

$\mathrm{K} 562$ is a chronic myeloid leukemia (CML)-derived cell line in which $\mathrm{c}-\mathrm{ab} /$ was translocated giving rise to a Bcr/Abl hybrid protein which was supposed to confer apoptosis resistance to K562 (Mac Gahon et al, 1994). We wondered if the increase in Abl antigen detected by FCM was due to $\mathrm{c}-\mathrm{ab}$ l overexpression or to bcr/abl translocation as in $\mathrm{K} 562$. We analyzed the c-abl and bcr/abl mRNA by RT-PCR in sensitive and resistant cell lines. As in K562, we found that
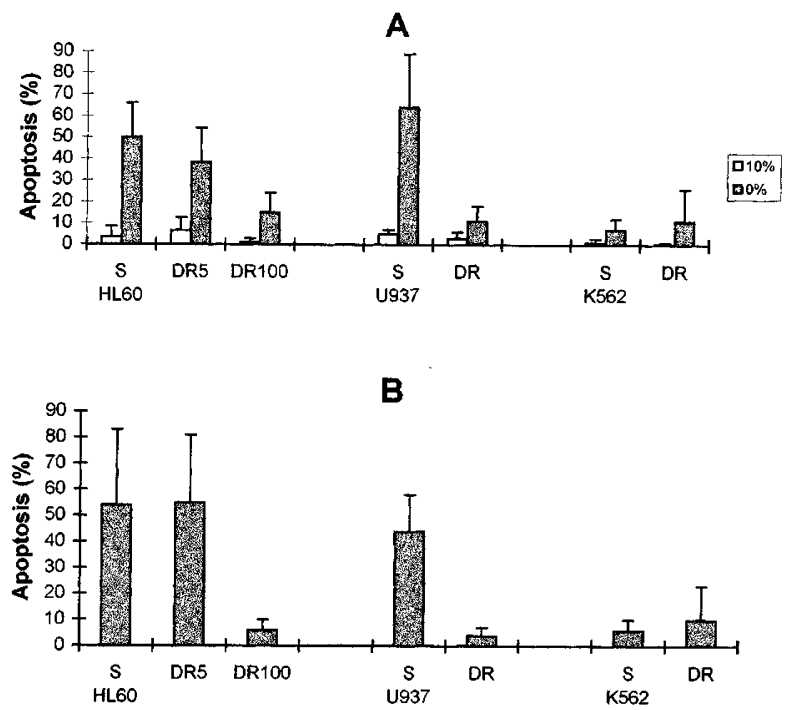

Figure 5 Effect of serum starvation and ceramide on sensitive and DR cells. (A) HL60, U937 and K562 cell lines and their DR sub-lines were cultured for $48 \mathrm{~h}$ in either $10 \%$ (grey bars) or $0 \%$ (dark bars) fetal calf serum. The percentage of apoptotic cells was determined as described in Materials and Methods. (B) The cells were treated with $50 \mu \mathrm{M}$ of C2-ceramide for $18 \mathrm{~h}$ and the percentage of apoptotic cells was determined as described in Materials and Methods. The means+S.D. of three to five separate experiments are shown.

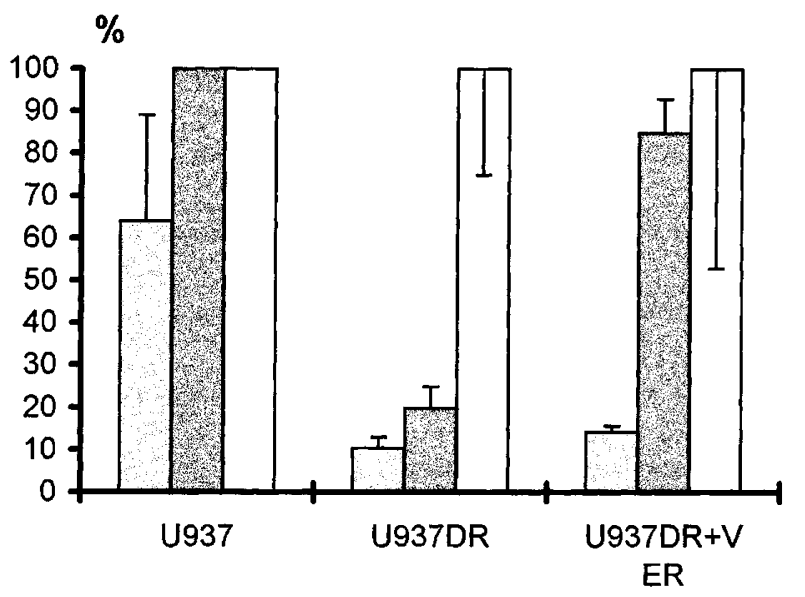

Figure 6 Effect of P-gp inhibition on the apoptosis induced by serum starvation on U937-DR cells. U937 or U937-DR cells were cultured in serumfree medium for $48 \mathrm{~h}$ in the absence or presence of $12 \mu \mathrm{M}$ verapamil (+VER). The percentage of apoptotic cells was determined as described in Materials and Methods (grey bars). The accumulation of Rh123 (dark bars) and of Bodipy-C2-ceramide (white bars) were measured by flow cytometry and the fluorescence expressed in percent of the sensitive U937 fluorescence. The means \pm S.D. of three separate experiments are shown. 
A

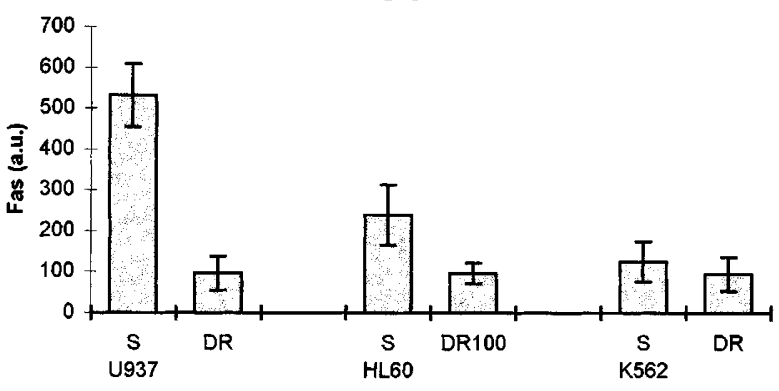

B

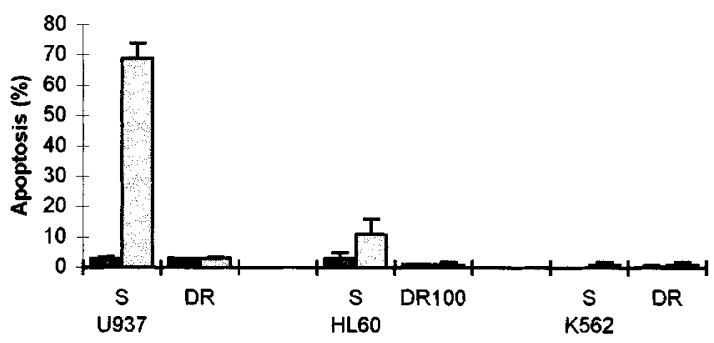

Figure 7 Comparative susceptibility of sensitive and DR cell lines to Fas mediated apoptosis. (A) Fas expression was measured by immunofluorescence and FCM on U937, HL60 and K562 sensitive and DR cells. The results are expressed in arbitrary fluorescence units. (B) U937, HL60 and K562 sensitive and DR cells were incubated for $18 \mathrm{~h}$ in the absence (dark bars) or the presence (gray bars) of $100 \mathrm{ng} / \mathrm{ml}$ of anti-Fas IgM (clone $\mathrm{CH} 11$, ImmunoTech, France) before apoptosis determination. The means \pm S.D. of triplicate samples are shown.

the bcr/abl hybrid mRNA was coexpressed with c-abl mRNA in the U937-DR and HL60-DR resistant cell lines (not shown). This hybrid mRNA coded for hybrid $210 \mathrm{kD}$ protein which was detected by Western blot beside the $145 \mathrm{kD}$ Abl protein in resistant and K562 cells, while only the $145 \mathrm{kD} \mathrm{Abl}$ protein was expressed in sensitive U937 and HL60 cells (Figure 8B).

The origin of the hybrid protein was probed at the DNA level using a FISH method which labelled the abl gene with red fluorescence and the bcr gene with green fluorescence (Figure 9A). In these conditions, the juxtaposition of abl and bcr genes in the bcr-abl translocation led to a yellow fluorescent signal (Figure 9B). Using this method, we observed that the yellow fluorescent signal was present in several copies $(>15)$ in all the four apoptosis-resistant cell lines (including drug sensitive K562), while it was absent in all the three apoptosis sensitive lines (including the HL60DR5) where number anomalies of bcr and abl were nevertheless found (Table 1).

\section{Discussion}

A drug-resistant, mdr-1 expressing, variant of the U937 leukemia cell line has been developed in our laboratory by

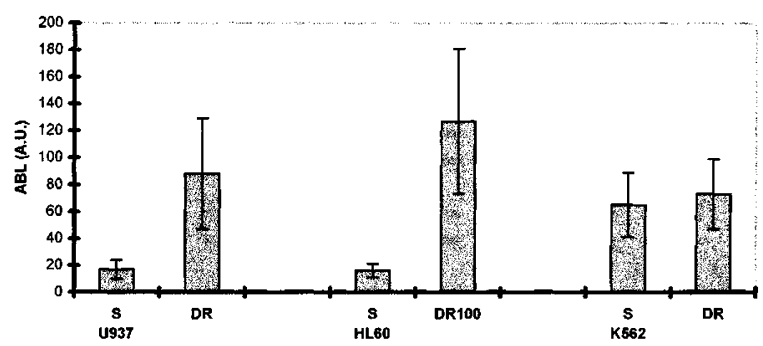

b
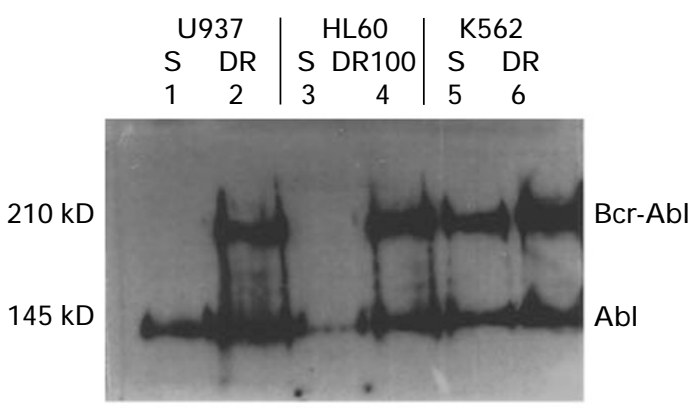

$46 \mathrm{kD}$

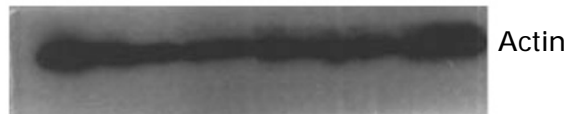

Figure 8 Expression of $\mathrm{Abl}$ in sensitive and DR cells. (A) Exponentially growing U937, HL60 and K562 sensitive and DR cells were fixed, permeabilised and labelled with a monoclonal anti-Abl antibody before FCM analysis as described in Materials and Methods. The means \pm S.D. of three separate experiments are shown. Expression of $c-a b l$ and bcr/abl in sensitive and DR cells. (B) Western blot analysis of Abl from U937 (1), U937-DR (2), HL60 (3), HL60-DR100 (4), K562 (5) and K562-DR (6) cells. The $145 \mathrm{Abl}$ and $210 \mathrm{kD} \mathrm{Bcr} / \mathrm{Abl}$ proteins and actin (as a loading control) are indicated.

continuous exposure to DNR (U937-DR). This variant was found to be able to undergo apoptosis, even when treated with very high concentrations of DNR which completely abolished cell growth (Durrieu et al, 1996). Moreover, it can be seen on Figures $3 \mathrm{~A}$ and $\mathrm{B}$ that Ara-C, an anti-metabolite which was not excluded by the mdr-1 product Pgp-170, was unable to induce apoptosis in the U937-DR cells while inhibiting DNA synthesis as efficiently as in the sensitive U937. This result is quite unusual because mdr-1 expressing cells are resistant only to natural compounds. In this work, we investigated in the mdr-1 expressing variants of three human myeloid leukemia cell lines (HL60, U937 and K562) the apoptosis induced by several stimuli. Cycloheximide (CHX), a protein synthesis inhibitor, which is not excluded by Pgp-170 failed to induce apoptosis in the U937-DR, HL60-DR100 and both sensitive and DR K562 cells. At the same time, the sensitive U937 and HL60 and an intermediary weakly resistant HL60-DR5 line readily underwent apoptosis.

When using a more physiologic triggering of apoptosis such as growth factor deprivation for $48 \mathrm{~h}$, the three variants with high mdr-1 expression and K562 showed a greatly reduced apoptotic response when compared to 
a

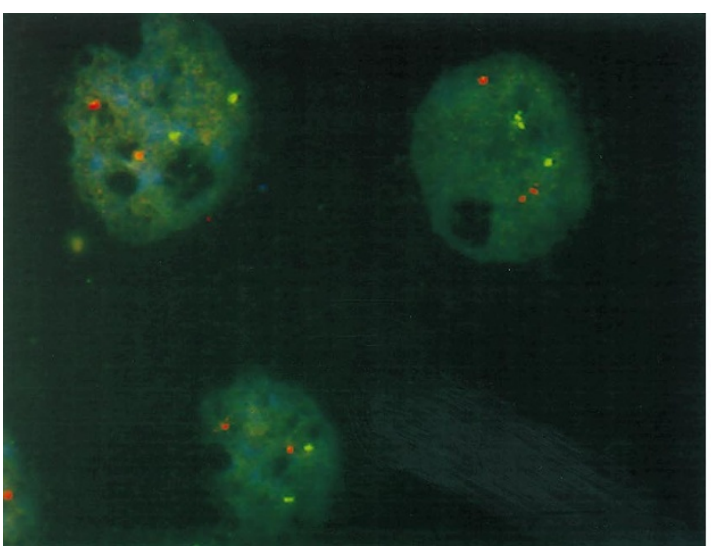

b

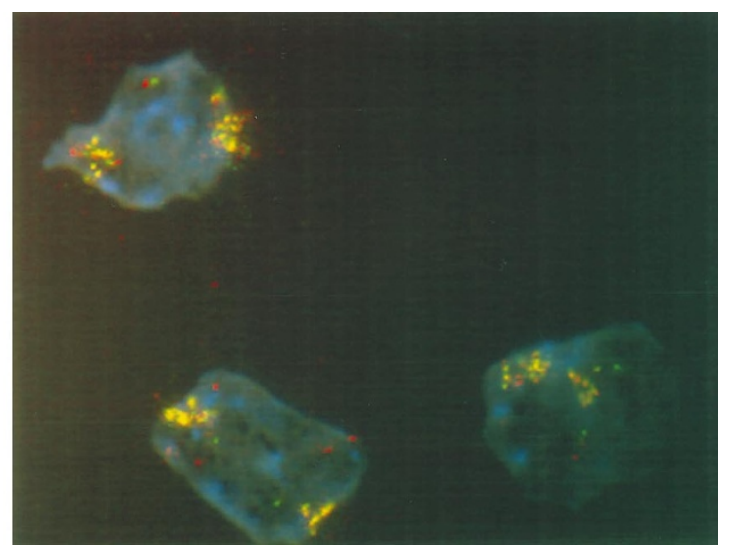

Figure 9 FISH for bcr and abl genes in HL60 (A) and HL60-DR100 (B) cell lines. The cytospins were hybridized with the LSI ${ }^{\mathrm{TM}}$ bcr/abl probe. C-ab/ copies appeared as red spots, c-bcr copies as green spots and bcr-abl rearrangement as yellow spots. (A) HL60 with two copies of both abl and bcr. (B) several copies of yellow-stained bcr-abl rearranged genes can be observed. $\times 200$.

HL60, HL60-DR5 and U937. At the same time, the growth was inhibited in all seven cell lines.

It is possible that the signal transduction pathway triggered by the growth factor receptors was uncoupled in the four apoptosis-resistant cell lines. This was thus shunted by using ceramide, the apoptosis second messenger, as inducer of apoptosis. Similar patterns of apoptosis resistance were found with ceramide as with growth factor deprivation. This apparent apoptosis-resistant phenotype could not be entirely explained by a defective transduction of the signal.

Other apoptosis-resistant cells have previously been described in association with drug resistance. In the Tlymphoblastoid cell line, MOLT-4, an adriamycin-resistant phenotype was developed and was attributed to apoptosis resistance (Frankfurt et al, 1994). A decrease in CD4 expression was detected when compared with the sensitive parental cell line. A cisplatine resistance was also obtained on a murine lymphoid cell line leading to an apoptosisresistant phenotype to the 5-azacytidine anti-metabolite (Segalbendrdijian and Jacquemìnsablon, 1996). The present work is the first report of such an apoptosis-resistant phenotype in myeloid p53 defective cell lines and in association with mdr-1 expression.

Overexpression of $\mathrm{Bcl}-2$ is known to reduce apoptosis potential but the relative content in $\mathrm{Bcl}-2$ in apoptosissensitive and resistant cell lines is not in favour of such a mechanism, because drug-resistant cell lines were found to contain a decreased steady state amount of Bcl-2 (Durrieu et al, 1996).

Fas has previously been described to participate in apoptosis induced by anthracyclines in lymphocytic leukemia cells, and T-cells, resistant to Fas-mediated apoptosis have been described as being resistant to anthracycline-induced apoptosis (Friesen et al, 1996). We thus investigated the expression and efficiency of Fas as a mediator of apoptosis in our myeloid cell lines. Fas expression was found to be dramatically low in all the apoptosis-resistant cell lines as compared to U937, and
Table 1 FISH analysis of cell lines with the $\mathrm{LSI}^{\mathrm{TM}}$ bcr/abl probe

\begin{tabular}{lccc}
\hline Cell lines & $\begin{array}{c}\text { Number } \\
\text { of abl } \\
\text { signals/cell }\end{array}$ & $\begin{array}{c}\text { Number } \\
\text { of bcr } \\
\text { signals/cell }\end{array}$ & $\begin{array}{c}\text { Number of } \\
\text { bcr-abl } \\
\text { signals/cell }\end{array}$ \\
\hline HL60 & 2 & 2 & 0 \\
HL60-DR5 & 2 & 2 & 0 \\
HL60-DR100 & 5 & 1 & $>15$ \\
U937 & 2 & 3 & 0 \\
U937-DR & 4 & 3 & $>15$ \\
K562 & 3 & 2 & $>15$ \\
K562-DR & 3 & 2 & $>15$ \\
\hline
\end{tabular}

they were unable to perform anti-Fas induced apoptosis. However, HL60 which was a good responder to other apoptosis stimulations (drugs, serum deprivation, ceramide) exhibited a low level of Fas expression and a reduced response to anti-Fas antibodies. Therefore, the rate of Fas expression could not account in itself for apoptosis resistance or sensitivity in our model.

Abl protein-tyrosine kinase was reported to be able to confer an apoptosis-resistant phenotype to leukaemia cell lines (Mac Gahon et al, 1994, 1995; Chapman et al, 1995). Thereafter, Abl became a good candidate to be investigated in apoptosis-resistant cells. We thus used immunofluorescence to measure the expression of $\mathrm{Abl}$ in the sensitive and resistant cell lines, and found that the apoptosis-resistant phenotype was accompanied by an homogenous increase in the Abl antigen content in all the four resistant cell lines. This is in agreement with previous results showing that Bcr-Abl confer an apoptosis-resistant phenotype to K562 (Mac Gahon et al, 1994), and that v-Abl can inhibit Fas-mediated apoptosis in HL60 (Mac Gahon et al, 1995). However, such an apoptosis-related function was never reported for normal Abl tyrosine kinase, and HL60 and U937 cells did not show the bcr/abl translocation, as is the case for K562. Therefore, we verified if this translocation had occurred during the development of multidrug/ apoptosis resistance. RT-PCR and Western-blot per- 
formed on sensitive and resistant cells clearly showed that U937-DR and HL60-DR100 cells had translocated their abl gene adjacent to the bcr region, which led to the expression of the hybrid mRNA and the $210 \mathrm{kD} \mathrm{Bcr} / \mathrm{Abl}$ protein. Moreover, FISH analysis at the DNA level showed that genic amplification of the translocated gene had occurred in all the apoptosis-resistant cell lines comprising the native K562. The intermediary resistant HL60-DR5 which expressed mdr-1 was found to be sensitive to apoptosis induction by $\mathrm{CHX}$, growth factor deprivation and ceramide and did not show any modification of bcr and abl genes when compared with the parental HL60 (Table 1). This strongly suggests that the translocation of abl and the amplification of the gene was induced by the incubation with DNR during the induction of the resistance rather than by the selection of a pre-existing translocated clone. Therefore, the apoptosis-resistant phenotype acquired during the development of multidrug resistance of U937 and HL60 cells was probably due to the over-expression of the $\mathrm{Bcr} / \mathrm{Abl}$ protein tyrosine kinase. It would be interesting to further investigate if this translocation is always observed in mdr-1 expressing HL60 and U937, if it is restricted to the myeloid cell lines or if similar observations could be performed on lymphoid and solid tumour cells.

In conclusion, we have demonstrated that the multidrugresistant phenotype can be accompanied by an apoptisisresistant phenotype independent of the mdr-1 expression in myeloid leukemia cell lines. Whether such an accompanying phenomenon occurs in clinical samples remains to be discovered. This is important because if this was the case, inhibiting the Pgp-170 pump with reverting agents would remain without effect on apoptosis potential. The inhibition of apoptosis by the Bcr/Abl protein kinase was not found to be ubiquitous, and normal rates of apoptosis were observed under UV irradiation or monensin treatment. A larger spectrum of drugs must now be assayed in an attempt to reverse the apoptosis resistance phenotype in $\mathrm{Bcr} / \mathrm{Abl}$ expressing cells. Moreover, investigations are now under way in our laboratory to determine the chronological chain of events leading to mdr-1 expression in one part and abl translocation and bcr-abl amplification on another part when cells are incubated with DNR.

\section{Materials and Methods}

\section{Cells}

The experiments were performed on human promyelocytic HL-60, monocytic U937 and undifferentiated K562 parental cell lines and on their mdr-1 expressing, resistant variants (HL60-DR, U937-DR and K562-DR). The three parental cell lines were known to be defective for p53 (Danova et al, 1990). The K562-DR cell line was kindly provided by Pr JP Marie (Hôtel Dieu, Paris, France).

The resistant subclones were obtained by culturing the parental cell line with progressively increasing concentrations of DNR (for U937 and K562) or Doxorubicin (for K562). During the induction of the resistance in the HL60 cell line, an intermediary resistant cell line able to grow in the presence of $5 \mathrm{ng} / \mathrm{ml}$ DNR was conserved in liquid nitrogen (HL60DR5). The DNR concentration was further increased to obtain another resistant cell line able to grow in $100 \mathrm{ng} / \mathrm{ml}$ DNR (HL60-DR100).
The cells were maintained in RPMI 1640 (Gibco-BRL) supplemented with $10 \%$ foetal calf serum (FCS), $1 \mathrm{mM}$ glutamine (Gibco$\mathrm{BRL}$ ), $10 \mathrm{mM}$ HEPES (Eurobio), 100 units/ml penicillin (Bio-Merieux), $50 \mu \mathrm{g} / \mathrm{ml}$ streptomycin (Bio-Merieux) in a humidified $5 \% \mathrm{CO} 2,37^{\circ} \mathrm{C}$ warmed incubator. The resistant cell lines were maintained in the presence of $100 \mathrm{ng} / \mathrm{ml}$ DNR except for HL60-DR5 which was maintained in the presence of $5 \mathrm{ng} / \mathrm{ml}$ DNR. All experiments were done on exponentially growing cells which were cultured in the absence of DNR for at least $48 \mathrm{~h}$.

\section{Apoptosis determination}

For U937 and K562 cell lines, apoptosis was determined by using Hoechst 33342 staining and analysis of the red/blue fluorescence ratio by flow cytometry (FCM) as previously described (Belloc et al, 1994) with an ATC 3000 cell sorter (Odam-Brucker, France using UV excitation with a 2025 Spectraphysics argon laser. Apoptotic cells were identified as a discrete population with increased red/blue fluorescence ratio.

This method was found not to be suitable to determine HL60 apoptosis and either the terminal deoxynucleotidyl transferase (TdT) or acridine orange assays were thus used for HL60. The acridine orange assay consisted in staining of cells in their culture medium with $10 \mu \mathrm{g} / \mathrm{ml}$ acridine orange (Molecular Probes) and analysis by fluorescence microscopy. Cells with condensed chromatin and/or fractionated nucleus were scored as apoptotic.

For the TdT assay, the cells were fixed and permeabilised using the Ortho-Permeafix (Ortho, France) reagent according to the supplier's instructions. Four $10^{5}$ fixed cells were rehydrated for $30 \mathrm{~min}$ in PBS, resuspended in $20 \mu \mathrm{l}$ of a solution containing 4.5 units of terminal deoxynucleotidyl transferase (TdT) (Promega), 3 pmoles of Fluorescein-12-dUTP (Boehringer-Mannheim) and $20 \mu \mathrm{M}$ dATP, dCTP and dGTP (Boehringer-Mannheim). The cells were then incubated in this solution for $1 \mathrm{~h}$ at $28^{\circ} \mathrm{C}$. After incubation in staining buffer, the cells were rinsed in PBS containing $0.1 \%$ Triton X-100 and resuspended in $1 \mathrm{ml}$ of PBS. The cells with fractionated DNA-labelled by fluorescent dUTP were identified by FCM analysis using an XL flow cytometer (Coultronics, France).

\section{BrdUrd analysis of DNA synthesis}

The cells were pulse-labelled with $30 \mu \mathrm{M}$ of BrdUrd (Sigma) for $30 \mathrm{~min}$ at $37^{\circ} \mathrm{C}$. After washing and centrifugation, cells were fixed with $50 \%$ ethanol in $50 \%$ PBS and stored at $-20^{\circ} \mathrm{C}$. Each sample was labelled as previously described (Lacombe et al, 1992). Briefly, the cells were treated with $2 \mathrm{~N} \mathrm{HCl}$ for $30 \mathrm{~min}$ at $20^{\circ} \mathrm{C}$ and washed three times with PBS $+0.5 \%$ Tween 20 . Samples were reacted with monoclonal antiBrdUrd antibody (IU-4, Caltag) for 30 min at $20^{\circ} \mathrm{C}$. After washing with PBS-Tween 20, cells were incubated with FITC-sheep anti-mouse Fab'2 (Sigma) for $30 \mathrm{~min}$ at $20^{\circ} \mathrm{C}$, washed and resuspended in PBS containing $10 \mu \mathrm{g} / \mathrm{ml}$ of PI (Calbiochem). Samples were ready for flow cytometry after $1 \mathrm{~h}$ at $4^{\circ} \mathrm{C}$. The rate of DNA synthesis inhibition was measured in S phase cells as described (Lacombe et al, 1992) on an ATC 3000 cell sorter (Odam-Brucker, France).

\section{Flow cytometry analysis of antigen expression}

Mdr-1 expression was relatively quantified at the Pgp-170 level by indirect immuno-labelling using the UIC2 anti-Pgp antibody (Immunotech, Marseille, France) on fixed permeabilised cells (Orthopermeafix, Ortho, France). The mean fluorescence channel was measured by FCM (Figure 1). A negative control was performed 
with an unrelated IgG2 primary antibody and its mean fluorescence channel was subtracted from all fluorescence values. The relative expression was calculated as the ratio of the fluorescence of the resistant cell line to the fluorescence of the sensitive parental cell line.

Fas expression was determined by direct immunolabelling on living cells using the UB2 anti-CD95 antibody coupled to FITC (Immunotech, Marseille, France) and FCM. Abl protein-tyrosine kinase expression was determined by indirect immuno-labelling using a monoclonal anti Abl antibody (clone 24-21, Ab-3, Oncogene Research, Calbiochem) on fixed permeabilised cells (Orthopermeafix, Ortho, France). The mean fluorescence channel of each sample was corrected for the fluorescence of an isotypic negative control and the results were presented in terms of arbitrary fluorescence units.

\section{Western blot analysis}

In $0.9 \% \mathrm{NaCl}, 10^{6}$ cells were washed and then suspended in a $100 \mu \mathrm{l}$ protease inhibitor cocktail $(0.5 \mathrm{mM}$ PMSF, $1 \mathrm{mM}$ EDTA, $0.5 \mathrm{mg} / \mathrm{ml}$ leupeptin, $0.7 \mathrm{mg} / \mathrm{ml}$ pepstatin $\mathrm{A}$ ) in $0.9 \% \mathrm{NaCl}$. Cells were then lysed by addition of $25 \mu \mathrm{l}$ of $5 \times$ sample buffer $(60 \mathrm{mM}$ Tris-HCl pH $6.8,25 \%$ glycerol, 2\% SDS, $0.7 \mathrm{M}$ 2-mercaptoethanol, $0.1 \%$ bromophenol blue), boiled for $2 \mathrm{~min}$, and centrifuged for $5 \mathrm{~min}$ at 14000 r.p.m. Total protein content was quantified in the sample prior to SDS - PAGE electrophoresis in $7.5 \%$ acrylamide gel. After electrotransfer to nitrocellulose, blots were incubated with preblocking solution $(0.5 \%$ low fat dry milk in PBS containing $0.5 \%$ Tween 20 ) for $1 \mathrm{~h}$ at room temperature followed by a $1 \mathrm{~h}$ incubation with $1 \mu \mathrm{g} / \mathrm{ml}$ anti Abl (clone 24-21, Ab-3, Oncogene Research, Calbiochem) and $1 \mu \mathrm{g} / \mathrm{ml}$ of anti $\beta$-actin (clone AC-15, Sigma) monoclonal primary antibodies. After washing, the blots were incubated for $1 \mathrm{~h}$ with anti-mouse peroxidase conjugated second antibody (Sigma) diluted 1:10 000. After washing, the antibodies were revealed using the $\mathrm{ECL}$ chemoluminescent kit (Amersham).

\section{Analysis of Pgp-170 activity}

U937 and U937-DR cells at a concentration of $5.10^{5}$ cells $/ \mathrm{ml}$ were incubated for $30 \mathrm{~min}$ in the presence of either $0.1 \mu \mathrm{M}$ Rhodamine 123 (Rh123) or $1 \mu \mathrm{M}$ Bodipy-C2-ceramide (Molecular Probes, Leiden, Netherlands). Cell fluorescence was then analyzed by FCM through a $530 \mathrm{~nm}$ PB filter using a XL cytometer (Coulter, France). The mean fluorescence channel was calculated and corrected for autofluorescence (unlabelled cells).

\section{RT - PCR}

Total cellular RNA was isolated from $10^{6}$ cells by TRIzol ${ }^{\circledR}$ (GIBCO/ $\mathrm{BRL}$, France)/chloroforme extraction and isopropanol precipitation. The yield of total RNA extraction was evaluated by agarose $(1 \%)$ gel electrophoresis. Ten $\mu \mathrm{l}$ of RNA solution were heated at $65^{\circ} \mathrm{C}$ for $10 \mathrm{~min}$ with $2 \mu \mathrm{l}$ of random hexamer primers $(30 \mu \mathrm{g} / \mathrm{ml})$, ice cooled and subjected to first strand DNA synthesis using 23 units of AMV reverse transcriptase (Promega) in $8 \mu \mathrm{l}$ RT-Mix containing each dXTP at a $500 \mu \mathrm{M}$ final concentration. The $20 \mu \mathrm{l}$ reaction mixture was maintained for $45 \mathrm{~min}$ at $37^{\circ} \mathrm{C}$. Amplification of selected sequences was performed in a $50 \mu \mathrm{l}$ total volume reaction mixture containing $5 \mu \mathrm{l}$ of cDNA-RNA hybrid, $1 \times$ PCR buffer $(\mathrm{KCl} 50 \mathrm{mM}$, Tris- $\mathrm{HCl} 10 \mathrm{mM} \mathrm{pH} \mathrm{9,}$ Triton X-100 0.1\%), $\mathrm{MgCl}_{2} 1.5 \mathrm{mM}$, dXTPs $200 \mu \mathrm{M}, 1$ unit Taq polymerase and 50 pmoles of specific primers using an automatic thermocycler (Wessex Instrumentation Ltd.).

The primer sequences used for $m d r 1$ amplification were $5^{\prime}$ CAATTGTACCCATCATTGCAATAGC- $3^{\prime}$ and 5'-ATACATCATTGCCTGGGTGAAGGA-3'. The samples were subjected to thirty-five amplification cycles, each cycle consisting of $1 \mathrm{~min}$ at $94^{\circ} \mathrm{C}, 1 \mathrm{~min}$ at $65^{\circ} \mathrm{C}$ and $1 \mathrm{~min}$ at $72^{\circ} \mathrm{C}$. The primers were designed to drive the amplification of a $252 \mathrm{bp}$ sequence encompassed by exons 21-22-23 of mdr1 gene. The amplification for abl and bcr/abl sequences was as previously described (Bilhou-Nabéra et al, 1992). Total mRNA was reverse-transcribed into cDNA using a random primer $(\mathrm{pd}(\mathrm{N}) 6$, Boehringer) in $1 \mathrm{X}$ Super Script buffer, $0.5 \mathrm{mM}$ dNTP each, $0.01 \mathrm{mM}$ DTT, $200 \mathrm{U}$ Super Script II reverse transcriptase (Gibco-BRL) for $1 \mathrm{~h}$ at $37^{\circ} \mathrm{C}$. PCR was performed on $5 \mu \mathrm{l}$ cDNA in $1 \times$ Taq buffer containing $1.5 \mathrm{mM} \mathrm{MgCl}_{2}, 0.2 \mathrm{mM}$ dNTP each, $1 \mathrm{U}$ Taq polymerase (Promega), $1 \mathrm{pM}$ appropriate primers. The reaction mix was overlaid with $100 \mu \mathrm{l}$ oil. The PCR cycling conditions were one cycle of $94^{\circ} \mathrm{C}$ for $3 \mathrm{~min}, 65^{\circ} \mathrm{C}$ for $1 \mathrm{~min} 30,72^{\circ} \mathrm{C}$ for $1 \min 30$, and 30 cycles of $94^{\circ} \mathrm{C}$ for $1 \min 30,65^{\circ} \mathrm{C}$ for $1 \min 30,72^{\circ} \mathrm{C} 1 \min 30$. The PCR fragments were $138 \mathrm{pb}$ for $a b l$ (and GCC GCT CGT TGG AAC TCC AAG G) and $379 \mathrm{pb}$ for bcr-abl (GAC CCG GAG CTT TTC ACC TTT AGT Tand GAA GAA GTG TTT CAG AAG CTT CTC C

The amplified DNA was then electrophoresed on a $2 \%$ agarose gel in Tris/borate/EDTA buffer and visualized by staining with ethidium bromide.

\section{Two-colour FISH}

Briefly, 30000 cells of each cell line were washed in PBS and carefully centrifuged (Cytospin 3, Shandon) for 5 min at 400 r.p.m. on Superfrost slides (CML, France). Cells were successively fixed for 20 min at $4^{\circ} \mathrm{C}$ in methanol (5 min); methanol-water (1:1) (5 min); methanol-acetic acid (3: 1). Preparations were treated with RNase A (100 $\mu \mathrm{g} / \mathrm{ml}$ in $2 \times \mathrm{SSC}$, $\mathrm{pH} 7$, Boehringer-Mannheim, France) and pepsin $(0.1 \mathrm{mg} / \mathrm{ml}$ in $\mathrm{HCl}$ $0.01 \mathrm{~N}$, Boehringer-Mannheim). A postfixation step with $1 \%$ formaldehyde (Fluka, France) in PBS containing $50 \mathrm{mM} \mathrm{MgCl}_{2}$ was included. The DNA of the preparations was denatured at $72^{\circ} \mathrm{C}$ in $75 \%$ formamide/ $2 \times \mathrm{SCC}$ for $5 \mathrm{~min}$. We used the $\mathrm{LSI}^{\mathrm{TM}}$ bcr/abl translocation probe (Vysis, France), composed of a mixture of a bcr probe directly labelled with SpectrumGreen ${ }^{\mathrm{TM}}$ fluorophore and an abl probe directly labelled with SpectrumOrange ${ }^{\mathrm{TM}}$ fluorophore in $10 \mu \mathrm{l}$ of the hybridization for $12 \mathrm{~h}$ in an humidified chamber at $37^{\circ} \mathrm{C}$. The slides were then washed for $3 \mathrm{~min}$ in $0.4 \times \mathrm{SSC}$ at $73^{\circ} \mathrm{C}$ and $3 \mathrm{~min}$ in $2 \times \mathrm{SSC} / 0.1 \% \mathrm{NP}-40$ at room temperature. DNA was counterstained with $0.2 \mu \mathrm{g} / \mu \mathrm{l}$ DAPI in 'antifading' solution (Vectashield ${ }^{\mathrm{TM}}$, Vector, France). The cells were observed with an Axioskop (Zeiss) fluorescence microscope equipped with a triple-pass filter.

\section{References}

Barry MA, Reynolds JE and Eastman A (1993) Etoposide-iduced apoptosis in human $\mathrm{HL}-60$ cells is associated with intracellular acidification. Cancer Res. 53: $2349-$ 2357

Belloc F, Dumain P, Boisseau MR, Jalloustre C, Reiffers J, Bernard P and Lacombe F (1994) A flow cytometric method using Hoechst 33342 and propidium iodide for simultaneous cell cycle analysis and apoptosis determination in unfixed cells. Cytometry 17: 59-65

Bilhou-Nabera C, Viard F, Marit G, Gharbi MJ, Salzes S, Reiffers J, Broustet A Bernard Ph (1992) Complete cytogenetic conversion in chronic myelocytic leukemia patients undergoing interferon alpha therapy: follow up with reverse polymerase chain reaction. Leukemia 6: 595-598

Boiron JM, Belloc F, Montastruc M, Cony-Makhoul P, Dumain P, Marit G, Mahon FX, Puntous M, Lopez F, Lacombe F, Reiffers J (1994) Flow cytometric study of Idarubicin and Daunorubicin accumulation and the effect of Verapamil in leukemic cell lines and fresh cells from patients with acute non-lymphoblastic leukemia. Leukemia Res. 18: 313-318 
Bose R, Verheij M, Haimovitz-Friedman A, Scotto K, Fuka Z and Kolesnick R (1995) Ceramide synthase mediates daunorubicin-induced apoptosis: an alternate mechanism for generating death signal. Cell 82: 405-414

Campos L, Rouault JP, Sabido O, Oriol P, Roubi N, Vasselon C, Archimbault E, Magaud JP and Guyotat D (1993) High expression of bcl-2 protein in acute myeloid leukemia cells is associated with poor response to chemotherapy. Blood 81: $3091-3096$

Chapman RS, Whetton AD, Chresta CM and Dive C (1995) Characterisation of drug resistance mediated via the suppression of apoptosis by Abelson protein tyrosine kinase. Mol. Pharmacol. 48: 334-343

Danova M, Giordano M, Mazzini G and Riccardi A (1990) Expression of p53 protein during the cell cycle measured by flow cytometry in human leukemia. Leuk. Res. 14: $417-422$

Durrieu F, Belloc F, Dumain P, Lacombe F and Bernard P (1996) Synthesis of BCL-2 could be responsible for the resistance of leukemic cell lines to apoptosis. British J. Haematol. 93, supl. 2: 342 (abstract)

Frankfurt OS, Seckinger D and Sugarbaker EV (1994) Pleiotropic drug resistance and survival advantage in leukemia cells with diminished apoptotic response. Int J. Cancer 59: 217-224

Friesen C, Herr I, Krammer PH and Debatin KM (1996) Involvement of the CD95 (APO-1/Fas) receptor/ligand system in drug-induced apoptosis in leukemia cells. Nature Medicine 2: $574-577$

Gorczyca W, Bigman K, Mittelman A, Ahmed T, Gong J, Melamed MR, Darzynkiewicz Z (1993) Induction of DNA strand breaks associated with apoptosis during treatment of leukemias. Leukemia 7: 659-670

Gottesman MM and Pastan I (1993) Biochemistry of multidrug resistance mediated by the multidrug transporter. Ann. Rev. Biochem. 62: 385-425

van Helvoort A, Smith AJ, Sprong H, Fritzsche I, Schinkel AH, Borst P and van Meer G (1996) MDR-1 P-glycoprotein is a lipid translocase of broad specificity, while MDR-3 P-glycoprotein specifically translocates phosphatidylcholine. Cell 87: $507-517$

Hicsonmez G, Erdemli E, Tekelioglu M, Tuncer AM, Ozbek N, Cetin M and Cotter TG (1996) Morphologic evidence of apoptosis in childhood acute myeloblastic leukemia treated with high-dose methylprednisolone. Leukemia and Lymphoma 22: $1-2$

Jaffrezou JP, Levade T, Bettaieb A, Andrieu N, Bezombes C, Maestre N, Vermeersch S, Rousse A and Laurent G (1996) Daunorubicin-induced apoptosis: Triggering of ceramide generation through sphingomyelin hydrolysis. EMBO J. 15: 24172424
Kolesnick RN, Haimovitzfriedman A and Fuks Z (1994) The sphygomyelin signal transduction pathway mediates apoptosis for tumor necrosis factor, fas and ionizing radiation. Biochem. Cell. Biol. 72: 11-12

Lacombe F, Belloc F, Dumain P, Puntous M, Lopez F, Bernard P Boisseau MR and Reiffers J (1992) Quantitation of resistance of leukemia cells to cytosine arabinoside from BrdUrd/DNA bivariate histograms. Cytometry 13: 730-738

Li X, Gong J, Feldman E, Seiter K, Traganos F, Darzynkiewicz Z (1994) Apoptotic cells during treatment of leukemias. Leukemia and Lymphoma 13: 65-70

Mac Gahon A, Bissonnette R, Schmitt M, Cotter KM, Green DR and Cotter TG (1994) BCR-ABL maintains resistance of chronic myelogenous leukemia cells to apoptotic cell death. Blood 83: 1179-1187

Mac Gahon AJ, Nishioka WK, Martin SJ, Mahmoubi A, Cotter TG and Green DR (1995) Regulation of the Fas apoptotic cell death pathway by Abl. J. Biol. Chem. 270: $22625-22631$

Maxfield FR (1982) Weak bases and ionophores rapidly and reversibly raise the $\mathrm{pH}$ of endocytic vesicles in cultured mouse fibroblasts. J. Cell. Biol. 95: 676-681

Miyashita T and Reed JC (1993) Oncoprotein blocks chemotherapy-induced apoptosis in human leukemia cell line. Blood 81: 151-157

Segalbendirdjian E and Jacqueminsablon A (1996) Cisplatin resistance in a murine leukemia cell line associated with a defective apoptotic process. Bull Cancer 83: $371-378$

Simon S, Roy D and Schindler M (1994) Intracellular pH and the control of multidrug resistance. Proc. Natl. Acad. Sci. USA. 91: 1128-1132

Vial, Belloc, Dumain, Besnard, Lacombe, Boisseau, Reiffers and Bernard (1996) Study of the apoptosis induced in vitro by antitumoral drugs on leukaemic cells. Leukemia Res. 19: in press

Weisburg JH, Curcio M, Caron PC, Raghu G, Mechetner EB, Roepe PD and Scheinberg DA (1996) The multidrug resistance phenotype confers immunological resistance. J. Exp. Med. 183: 2699-2704

Wright SC, Zheng H and Zhong J (1996) Tumor cell resistance to apoptosis due to a defect in the activation of sphingomyelinase and the $24 \mathrm{kDa}$ apoptotic protease (AP24). FASEB J. 10: 325-332

Wyllie AH (1992) Apoptosis and the regulation of cell numbers in normal and neoplastic tissues: an overview. Cancer and Metastasis Rev. 11: 95-103 